\title{
Clodronate alleviates cachexia and prolongs survival in nude mice xenografted with an anaplastic thyroid carcinoma cell line
}

\author{
Cheng-Hsu Wang ${ }^{1,2}$, Yung-Chi Shen ${ }^{1}$, Jia-Juan Hsieh ${ }^{2}$, Kun-Yun Yeh ${ }^{1,2}$ and John Wen-Cheng Chang ${ }^{2}$ \\ ${ }^{1}$ Division of Hematology/Oncology, Department of Internal Medicine, Chang Gung Memorial Hospital, Chang Gung University College of Medicine, \\ Keelung 204, Taiwan \\ ${ }^{2}$ Division of Hematology/Oncology, Department of Internal Medicine, Chang Gung Memorial Hospital, Chang Gung University College of Medicine, 5 , \\ Fu-Hsing Street, Taoyuan 333, Taiwan \\ (Requests for offprints should be addressed to J W-C Chang; Email: wen1902@hotmail.com)
}

\begin{abstract}
Cancer cachexia is one of the most common manifestations of advanced malignant disease and is frequently associated with decreased survival. Previously, we reported the establishment of a new anaplastic thyroid carcinoma cell line, Thena, and its mouse xenograft, Thena-Nu, which induced cachexia in athymic nude mice. Subsequent studies showed that the addition of clodronate to Thena-Nu cultures reduced cell proliferation as well as cytokine production in a dose- and timedependent manner. Weekly administration of clodronate induced tumor cytostasis, attenuation of cachexia, as well as prolongation of survival in Thena-Nu-bearing mice. Reduced

serum interleukin 6 , tumor necrosis factor- $\alpha$, and granulocyte colony stimulating factor levels were detected, whereas, serum leukemia inhibitory factor levels were not reduced. Liver necrosis, observed in tumor-bearing mice, was also improved following clodronate treatment. Discontinuation of clodronate treatment, however, resulted in progressive tumor growth and weight loss. Our results demonstrated that clodronate could exert therapeutic efficacy on amelioration of cancer cachexia in the hosts. Nevertheless, this study also points out that a longer period of treatment is required to maintain these effects.

Journal of Endocrinology (2006) 190, 415-423
\end{abstract}

\section{Introduction}

Cachexia is a paraneoplastic syndrome manifested as progressive weight loss with depletion of adipose tissue and skeletal muscle, and contributes to a poor quality of life, which is observed in about half of all the cancer patients after the onset of disease (Tisdale 2002). Proinflammatory cytokines, including tumor necrosis factor (TNF)- $\alpha$, interleukin (IL)-1, IL-6, leukemia inhibitory factor (LIF), and interferon $\gamma$, have been proposed as mediators of cancer cachexia (Noguchi et al. 1996). Various agents demonstrated to suppress cytokine secretion, such as corticosteroid, megastrol acetate, medroxyprogesterone acetate, and thalidomide (Loprinzi et al. 1993, Mantovani et al. 1998), have been administered in attempts to retard or to halt progressive cachexia in cancer patients. Positive outcome in the reverse of anorexia and weight loss was observed in some randomized studies; however, no survival advantage was reported.

It was further identified that ATP-ubiquitin-dependent proteolysis was responsible for muscle wasting (Llovera et al. 1995), which has been shown to be upregulated by TNF- $\alpha$ and IL-6 (Tsujinaka et al. 1996, Llovera et al. 1997). Recently, TNF$\alpha$-induced activation of nuclear factor- $\kappa \mathrm{B}(\mathrm{NF}-\kappa \mathrm{B})$, a transcription factor regulating the expression of a variety of cytokines (Yamamoto \& Gaynor 2001), was implicated as playing a major role in muscle protein loss in vitro and in vivo by destabilizing $M y o D$, leading to the inhibition of myogenesis (Langen et al. 2004). The complexity of cancer cachexia has thus made the treatment regimen even more complex. In this regard, drugs able to intervene in the above-mentioned pathways should be considered as potential candidates for treating cancer cachexia.

Clodronate is a non-nitrogen containing bisphosphonate and has been widely used in the treatment of bone complications arising from malignancy. Adjuvant clodronate was proven to reduce bone as well as non-osseous metastases in a randomized clinical trial on breast cancer (Diel et al. 1998), suggesting that clodronate not only elicits effects on osteoclasts, but also on tumor cells. In vitro studies showed that clodronate was metabolized by mammalian cells to a non-hydrolyzable ATP analog, adenosine $5^{\prime}$-( $\beta, \gamma$-dichloromethylene) triphosphate $\left(\mathrm{AppCCl}_{2} \mathrm{p}\right)$, a process catalyzed by several aminoacyl-tRNA synthetases. This incorporation may result in inhibition of tRNA aminoacylation by these enzymes, leading to inhibition of protein synthesis (Rogers et al. 1996, Frith et al. 1997). Clodronate was demonstrated to downregulate the production of IL-6 and TNF- $\alpha$ (Monkkonen et al. 1994), as well as NF- $\mathrm{KB}$ activation (Makkonen et al. 1999) in mouse macrophage-like RAW264 cells stimulated with lipopolysaccharides; inhibition of IL-6 production by osteosarcoma MG-63 cells was also 
documented (Giuliani et al. 1998). Cancer patients receiving clodronate treatment showed reduction in serum IL-6 levels, which was not associated with cytotoxic effects (Sauty et al. 1996). These results suggest that clodronate may possess therapeutic potential for cancer cachexia.

Recently, we reported the establishment of a new anaplastic thyroid carcinoma cell line, Thena, and its nude mouse xenograft, Thena- $\mathrm{Nu}$, producing high levels of proinflammatory cytokines, including IL-6, LIF, and TNF- $\alpha$, and inducing cachexia in athymic nude mice (Chang et al. 2003). In the present study, we would like to evaluate the effects of clodronate in Thena-Nu cells in vitro as well as in Thena-Nu-bearing nude mice.

\section{Materials and Methods}

\section{In vitro cell growth}

Cells were seeded to six-well plates (Nunc, Roskilde, Denmark) at $1 \times 10^{5}$ per well in RPMI medium (Invitrogen) containing 5\% fetal bovine serum (FBS; HyClone, Logan, UT, USA), supplemented with $2 \mathrm{mM}$ L-glutamine, $1 \mathrm{mM}$ sodium pyruvate, and $50 \mathrm{units} / \mathrm{ml}$ penicillin $-50 \mu \mathrm{g} / \mathrm{ml}$ streptomycin (Invitrogen). Culture supernatants were discarded following overnight incubation and replaced by fresh medium containing 2\% FBS and various concentrations of clodronate (disodium clodronate; Schering, Jena, Germany). Triplicate wells were harvested for 3 consecutive days. Culture supernatants were collected for cytokine assay. Cell number and viability were determined by the Trypan Blue exclusion method. Cell proliferation assay was performed by dimethylthiazolyl and thymidine incorporation methods.

\section{Cell-cycle analysis}

Following incubation with various concentrations (100$400 \mu \mathrm{g} / \mathrm{ml}$ or $400-1600 \mu \mathrm{M})$ of clodronate for $72 \mathrm{~h}$, cells were harvested, washed with PBS, and fixed in $75 \%$ ethanol for $2 \mathrm{~h}$ at $-20^{\circ} \mathrm{C}$. After incubation, cells were treated with $100 \mu \mathrm{g} / \mathrm{ml}$ propidium iodide (Sigma) in PBS containing 1\% glucose and $20 \mu \mathrm{g} / \mathrm{ml} \mathrm{RNase}$ for $30 \mathrm{~min}$ at room temperature. DNA content of stained cells was analyzed by flow cytometry.

\section{Tumor inoculation and clodronate treatment}

Athymic nude mice (Balb/c nu/nu, 8 weeks old), purchased from the Animal Facility of the National Science Council, Taiwan, were injected s.c. with $5 \times 10^{6}$ cells in $0 \cdot 1 \mathrm{ml}$ PBS in the right hind leg. Tumor growth was monitored every other day. Tumor size was measured with a caliper and tumor volume was calculated by the formula: $\left(a b^{2}\right) / 2$; where $a$ represents the longer diameter and $b$ is the shorter diameter of tumors (Tamura et al. 1995). Body weight of mice was measured once a week with a digital scale. Signs of s.c. fat or muscle wasting were grossly observed as well. Treatment was started at tumor size 6-8 $\mathrm{mm}$ in diameter, which is comparable to advanced stage in human (Kelland 2004). Tumor-bearing mice were either injected with $200 \mu \mathrm{g}(0.816 \mu \mathrm{mol})$ clodronate in $0.1 \mathrm{ml}$ normal saline (clodronate, $n=5$ ) or with $0.1 \mathrm{ml}$ normal saline (untreated, $n=6$ ) around tumors intradermally; non-tumorbearing mice (control, $n=4$ ) received $0.1 \mathrm{ml}$ normal saline weekly. Treatment was given for 8 consecutive weeks followed by 2 -week observation. Mice presenting with poor activity and severe cachexia were presumed dead and were killed; others were killed at day 90 after tumor inoculation. Serum was collected for cytokine assay; livers and spleens were fixed in formaldehyde for histopathological check using hematoxylin and eosin (H\&E) stain. All procedures used in this animal study were performed in accordance with institutional guidelines for animal care at Chang Gung Memorial Hospital.

\section{ELISA}

Levels of IL-6, LIF, and TNF- $\alpha$ in culture supernatants or mouse serum were determined by the ELISA method following the instructions of the manufacturer (R\&D Systems, Minneapolis, MN, USA). Since massive neutrophil infiltration was observed in primary tumor sections, levels of granulocyte colony stimulating factor were also evaluated. In brief, samples were loaded to 96-well plates precoated with anti-cytokine antibody and incubated at room temperature for $2 \mathrm{~h}$. After three washes, horseradish peroxidase (HRP)-conjugated secondary antibody was added and the plate was further incubated for $2 \mathrm{~h}$. A chromogen (tetramethylbenzidine and hydrogen peroxide mixed at 1:1) was then added for color formation. The reaction was stopped by the addition of $2 \mathrm{M} \mathrm{H}_{2} \mathrm{SO}_{4}$. Results were read with a Dynex MRXII ELISA reader (ThermoLabsystems, Chantilly, VA, USA) at $450 \mathrm{~nm}$ with correction at $570 \mathrm{~nm}$. The sensitivities of the kits are as follows: IL-6, $0.7 \mathrm{pg} / \mathrm{ml}$; LIF, $8 \mathrm{pg} / \mathrm{ml}$; TNF- $\alpha, 1 \cdot 6 \mathrm{pg} / \mathrm{ml}$; and G-CSF, $20 \mathrm{pg} / \mathrm{ml}$.

\section{In situ apoptosis stain}

To determine whether clodronate induced tumor apoptosis in vivo, paraffin sections $(5 \mu \mathrm{m})$ of mouse xenograft tumors were stained by terminal deoxynucleotidyl transferase (TdT)mediated dUTP nick end labeling method (TUNEL) according to the recommendation of the manufacturer (R\&D Systems). In brief, following fixation and rehydration, the cells were incubated with proteinase $\mathrm{K}$, quenched with methanol containing 3\% hydrogen peroxide, and labeled with a mixture containing TdT and brominated dNTPs at $37^{\circ} \mathrm{C}$ for $1 \mathrm{~h}$ in a humidified chamber. Reaction was stopped by immersing in $0 \cdot 01 \mathrm{M}$ EDTA. Samples were then incubated with anti-bromodeoxyuridine antibody followed by streptavidin-HRP. Sections were stained with $3-3^{\prime}$ diaminobenzidine tetrachloride and counterstained with Methyl Green. Results were evaluated with a light microscopy.

\section{Statistical analysis}

All values are expressed as means \pm s.D. Differences in cytokine levels in culture supernatants or mouse serum, tumor size, and body weight were analyzed using Student's $t$-test. Differences 
in survival were analyzed by Kaplan-Meier's method. $P$ values less than $0 \cdot 05$ were considered statistically significant.

\section{Results}

Clodronate inhibited cell proliferation and reduced cytokine secretion in vitro

In our previous report, we demonstrated that cells derived from Thena nude mouse xenograft (Thena-Nu) produced even higher levels of cytokines in the culture supernatants than their parental counterparts (Chang et al. 2003). Therefore, Thena-Nu cells were used in this study. In vitro cell growth assay demonstrated that clodronate had a doseand time-dependent effect on the inhibition of cell proliferation. As illustrated in Fig. 1A, $100 \mu \mathrm{g} / \mathrm{ml}$ clodronate did not inhibit growth of Thena-Nu cells at all time points tested. Clodronate at $200 \mu \mathrm{g} / \mathrm{ml}$ did not inhibit cell growth until drug exposure for $72 \mathrm{~h}(P<0 \cdot 05)$; whereas a significant reduction in total cell number was observed in cells

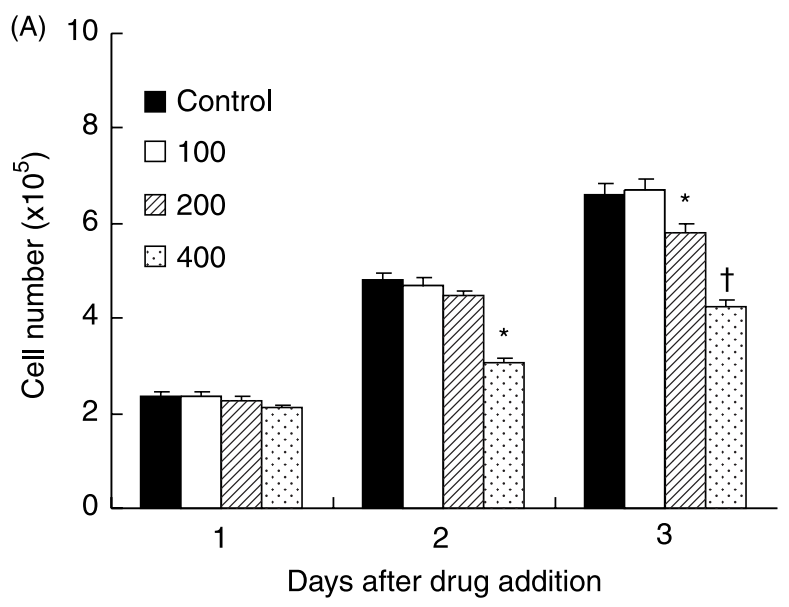

(B)

a



C

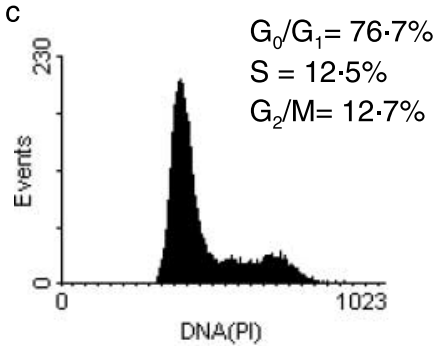

b

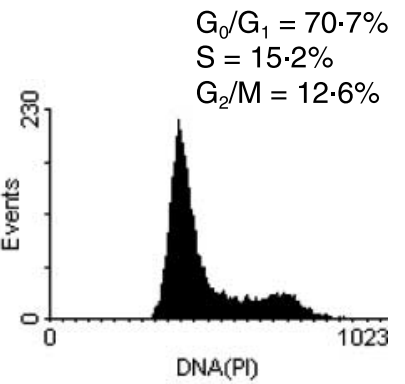

d

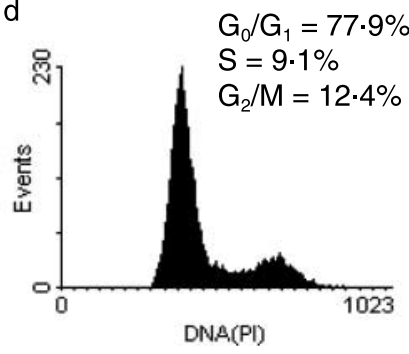

Figure 1 Inhibition of Thena-Nu cell growth by clodronate treatment. Cells were seeded to six-well plates at $1 \times 10^{5} /$ well. Following overnight incubation the medium was discarded and fresh medium containing different concentrations of clodronate $(100,200$, or $400 \mu \mathrm{g} / \mathrm{ml})$ was added. Medium alone served as control. Triplicate wells of each set were harvested. (A) Total viable cell number was counted by Trypan Blue dye exclusion. (B) Flow cytometric analysis demonstrated a slight accumulation in $\mathrm{G}_{0} / \mathrm{G}_{1}$ phase with a slight reduction in both $\mathrm{S}$ phase and $\mathrm{G}_{2} / \mathrm{M}$ phase in a dose-response manner. a, Medium alone; b, $100 \mu \mathrm{g} / \mathrm{ml}$; , $200 \mu \mathrm{g} / \mathrm{ml}$; and d, $400 \mu \mathrm{g} / \mathrm{ml}$. ${ }^{*} P<0 \cdot 05$ and ${ }^{\dagger} P<0 \cdot 01$ compared with control. 
incubated with $400 \mu \mathrm{g} / \mathrm{ml}$ clodronate for $48 \mathrm{~h}(P<0 \cdot 01)$. Cell-cycle analysis showed that treatment with 200 and $400 \mu \mathrm{g} / \mathrm{ml}$ clodronate for $72 \mathrm{~h}$ induced a significant accumulation in $\mathrm{G}_{0} / \mathrm{G}_{1}$ phase accompanied with a significant decrease in both $\mathrm{S}$ and $\mathrm{G}_{2} / \mathrm{M}$ phases, whereas $100 \mu \mathrm{g} /$ $\mathrm{ml}$ generated a slight decrease in $\mathrm{G}_{2} / \mathrm{M}$ phase (Fig. 1B). Proliferation assay showed comparable results to those obtained from the growth curve assay (data not shown), indicating that clodronate at these doses did not induce significant cell death.

Incubation of Thena- $\mathrm{Nu}$ cells in the presence of clodronate also exhibited a dose- and time-dependent effect in the reduction of IL-6, LIF, TNF- $\alpha$, and G-CSF production (Fig. 2). Treatment of Thena-Nu cells with $200 \mu \mathrm{g} / \mathrm{ml}$ clodronate induced a $>40 \%$ reduction in cytokine production following a 72-h incubation accompanied with only a slight decrease in cell number $(\sim 12 \%)$. Interestingly, $100 \mu \mathrm{g} / \mathrm{ml}$ clodronate did not induce growth inhibition in Thena-Nu cells, but significantly decreased their cytokine production after a 48- or 72-h exposure. These results suggest that growth inhibitory effects of clodronate may ascribe to its ability to reduce autocrine/paracrine factors for cell growth. To better clarify the capability of clodronate to downregulate production of proinflammatory cytokines in the subsequent animal experiments, $200 \mu \mathrm{g}$ is chosen due to its ability to induce a $\sim 50 \%$ cytokine inhibitory effect following a $72-\mathrm{h}$ exposure.

Clodronate induced tumor cytostasis, alleviated body weight loss, and prolonged survival of tumor-bearing mice

We investigated the effects of clodronate on thyroid cancer in vivo. Eighteen days following Thena-Nu cells inoculation tumors grew to a total volume between 205 and $320 \mathrm{~mm}^{3}$, mimicking the advanced stage of human cancer. Clodronate treatment was then started on day 19. The tumor stopped growing in the clodronate-treated group for more than a month, whereas rapid tumor growth was observed in untreated mice (Fig. 3A). Discontinuation of clodronate treatment resulted in a rapid tumor re-growth.

Subcutaneous fat wasting around the injection site was observed in tumor-bearing mice 15 days following inoculation. Significant difference on body weight between nontumor-bearing $(18.73 \pm 0.64 \mathrm{~g})$ and tumor-bearing $(17 \cdot 55 \pm 0 \cdot 20 \mathrm{~g})$ mice was seen on day $18(P<0 \cdot 05$, Fig. 3B). Clodronate induced a slight but not significant body weight gain in tumor-bearing mice 2 weeks after treatment, whereas untreated mice showed a gradually decreased body weight. On day 32 , a significant difference in body weight between clodronate-treated $(18 \cdot 18 \pm 0 \cdot 32 \mathrm{~g})$ and untreated $(17 \cdot 14 \pm 0 \cdot 42 \mathrm{~g})$ groups was seen $(P<0 \cdot 05)$. Compared with the untreated group, clodronate-treated mice disclosed a sustained body weight and a reduced severity of s.c. fat wasting around the injection site for up to 5 weeks (data not shown). However, progressive weight loss was demonstrated after clodronate discontinuation. An inverse
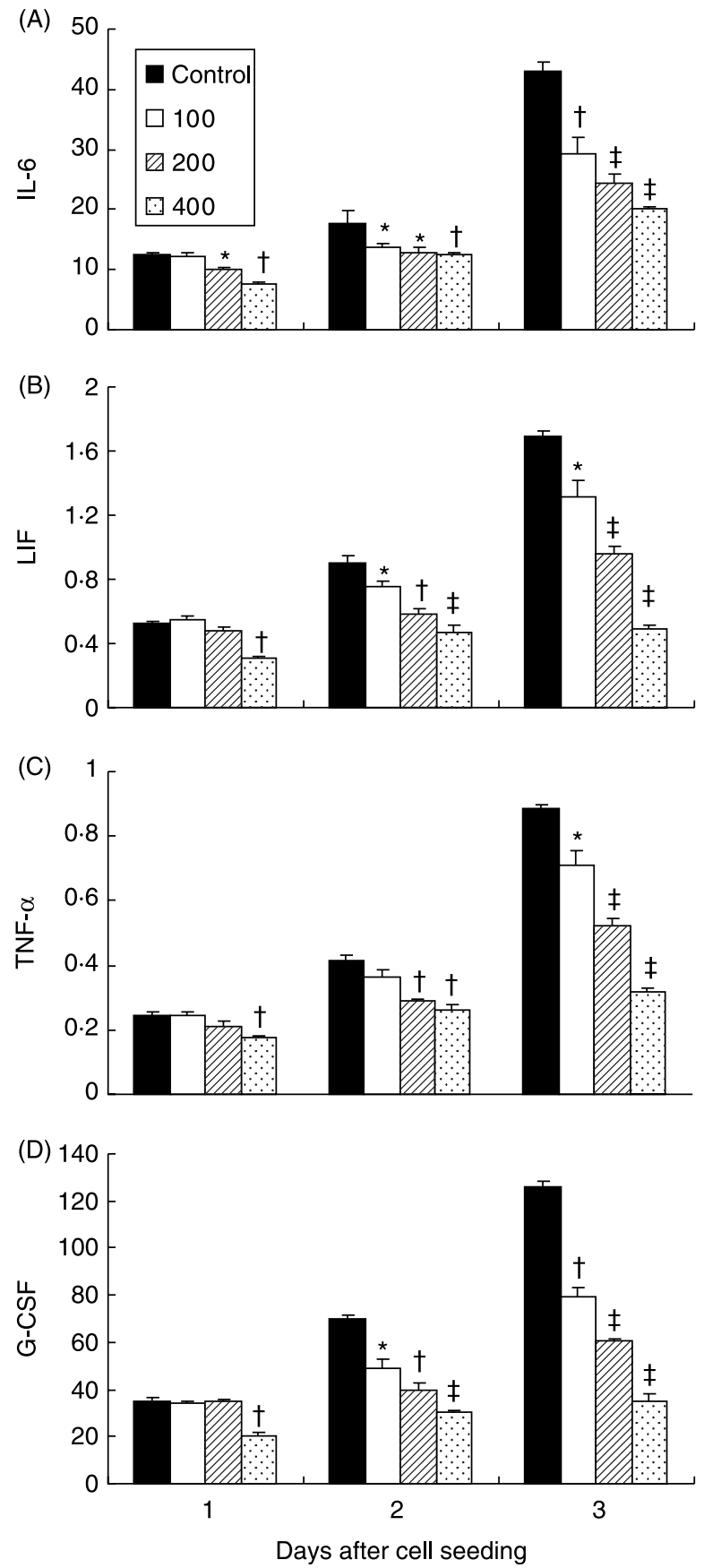

Figure 2 Reduction of cytokine secretion in Thena-Nu cells by clodronate treatment $(100,200,400 \mu \mathrm{g} / \mathrm{ml})$. Culture supernatants collected from the growth curve assay (Fig. 1) were assayed for content of cytokines, including (A) IL-6, (B) LIF, (C) TNF- $\alpha$, and (D) G-CSF. Results are expressed as nanogram per $10^{6}$ cells. ${ }^{*} P<0 \cdot 05$, ${ }^{\dagger} P<0 \cdot 01$, and ${ }^{\ddagger} P<0 \cdot 001$ compared with control.

relationship between tumor size and body weight in untreated mice was obtained $\left(r^{2}=0 \cdot 6201\right.$, data not shown).

A significantly longer survival was seen in the clodronatetreated group than the untreated group (Fig. $4, P<0 \cdot 01$ ). 
(A)
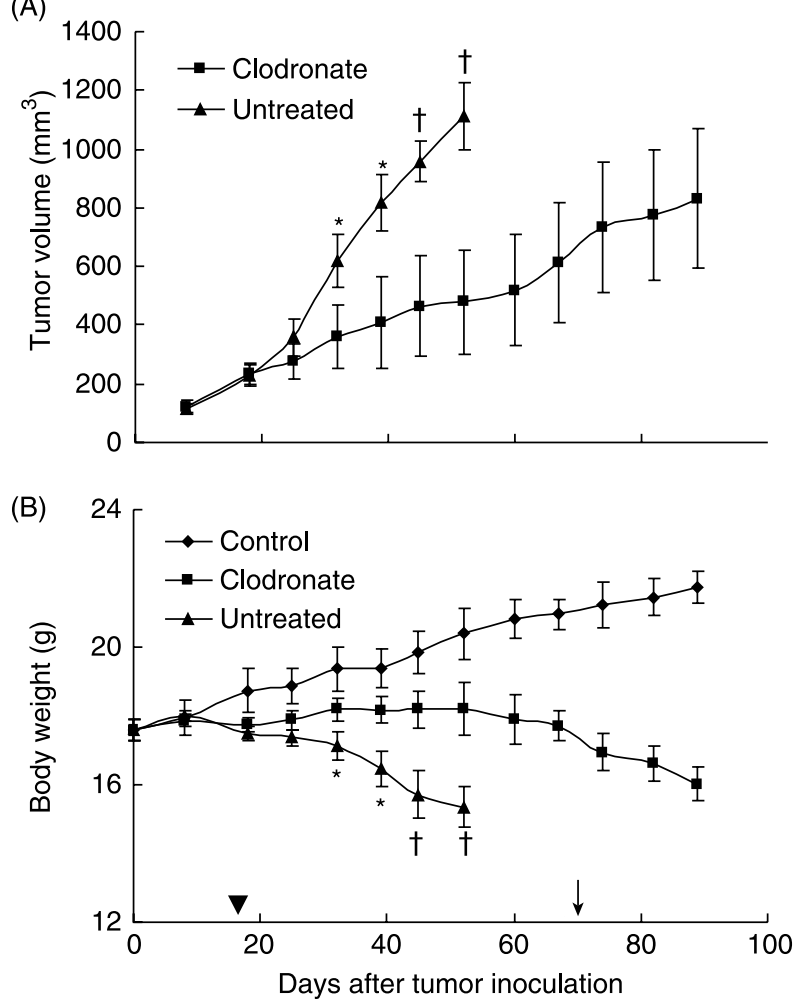

Figure 3 (A) Inhibition of tumor growth and (B) preservation of body weight in Thena-Nu-bearing mice with clodronate treatment. Tumor-injected mice were treated with clodronate (clodronate, $200 \mu \mathrm{g}$ in $0.1 \mathrm{ml}$ normal saline) or with normal saline (untreated, $0 \cdot 1 \mathrm{ml}$ ), starting from day 19 , once a week for 8 consecutive weeks, followed by 2 weeks of observation. Tumor volume and body weight of mice were measured once per week. Non-tumor-bearing mice (control) were included for comparison. Arrowhead denotes date of starting treatment and arrow, final treatment. ${ }^{*} P<0.05$ between untreated and clodronate and ${ }^{\dagger} P<0 \cdot 01$ between untreated and clodronate.

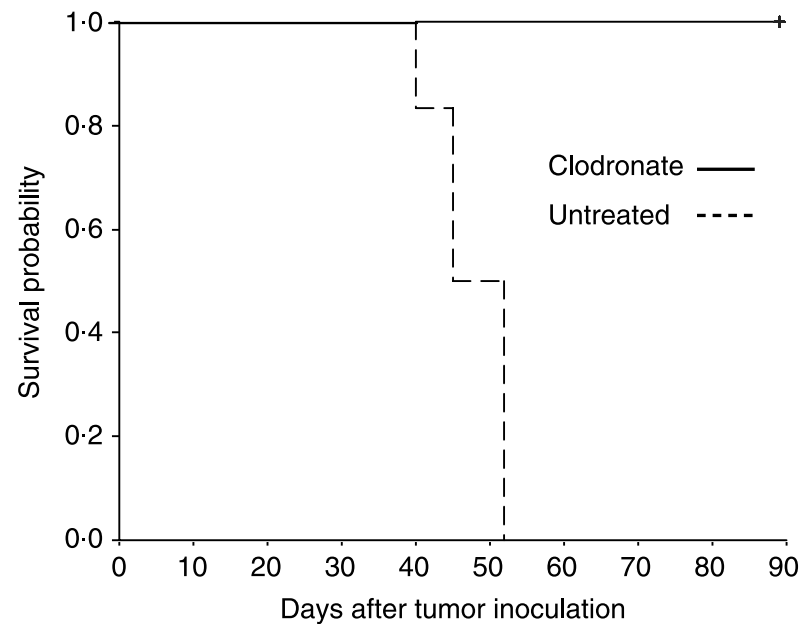

Figure 4 Prolongation of survival in Thena-Nu-bearing mice by clodronate treatment Clodronate $(-), n=5$; untreated $(---), n=6$ $(P<0 \cdot 05)$.
All the untreated mice became moribund before day 54, whereas all the clodronate-treated mice survived to the end of this study (day 90).

\section{Clodronate reduced liver necrosis in tumor-bearing mice}

H\&E staining showed that degenerated hepatocytes, accompanied with profound neutrophil infiltration were presented in liver sections of both groups. Neither tumor metastasis nor hepatomegaly was observed. Massive liver necrosis was found in 6/6 untreated tumor-bearing mice (Fig. 5A), whereas only very few small foci of necrotic areas were observed in livers of $2 / 5$ clodronate-treated mice. Survival of tumor-bearing mice seemed to be correlated with the severity of liver necrosis. However, liver sections of clodronate-treated mice showed more intensive neutrophil infiltration, prominently around portal veins, than untreated ones (Fig. 5B). Marked splenomegaly ( $>$ sevenfold) was found in tumor-bearing mice, despite clodronate treatment, and no difference in spleen pathology was observed (data not shown). Sections of tumor tissues from both groups were evaluated for apoptosis by TUNEL stain and no tumor apoptosis was seen (data not shown), indicating that attenuation of cancer cachexia was not due to induction of tumor apoptosis by clodronate.

Clodronate treatment reduced serum levels of human cytokines in cachectic nude mice

High levels of human IL-6, LIF, and G-CSF, as well as low levels of TNF- $\alpha$ were detected in the sera of tumor-bearing mice. A significant decrease in serum IL-6, TNF- $\alpha$, and G-CSF was obtained in mice treated with clodronate, whereas there was no difference in levels of LIF for both groups, as depicted in Table 1. None of these four human cytokines were detectable in sera of non-tumor-bearing mice.

To investigate the levels of cytokines in tumor tissue extracts, weighed tissues were immersed in $1 \mathrm{ml}$ PBS, homogenized, centrifuged, and supernatants were collected and assayed for cytokine contents. Levels of human IL-6 were greatly reduced in tumors of clodronate-treated mice $(P<0 \cdot 01)$. Although slightly decreased, there was no significant difference in the levels of G-CSF and TNF- $\alpha$ between both groups. Again, no decrease in levels of LIF for both groups was obtained (Table 1).

\section{Discussion}

Various cytokines have been postulated to be responsible for the metabolic changes in cachexia of mouse xenograft models (Noguchi et al. 1996). So far, only a few anti-cachectic drugs were applied to these animal models to evaluate their therapeutic efficacy (Tamura et al. 1995, Kurebayashi et al. 1999). However, no anti-tumor effect and survival impact were discussed. Furthermore, most experiments were conducted shortly after tumor implantation, which might be less clinically relevant. 

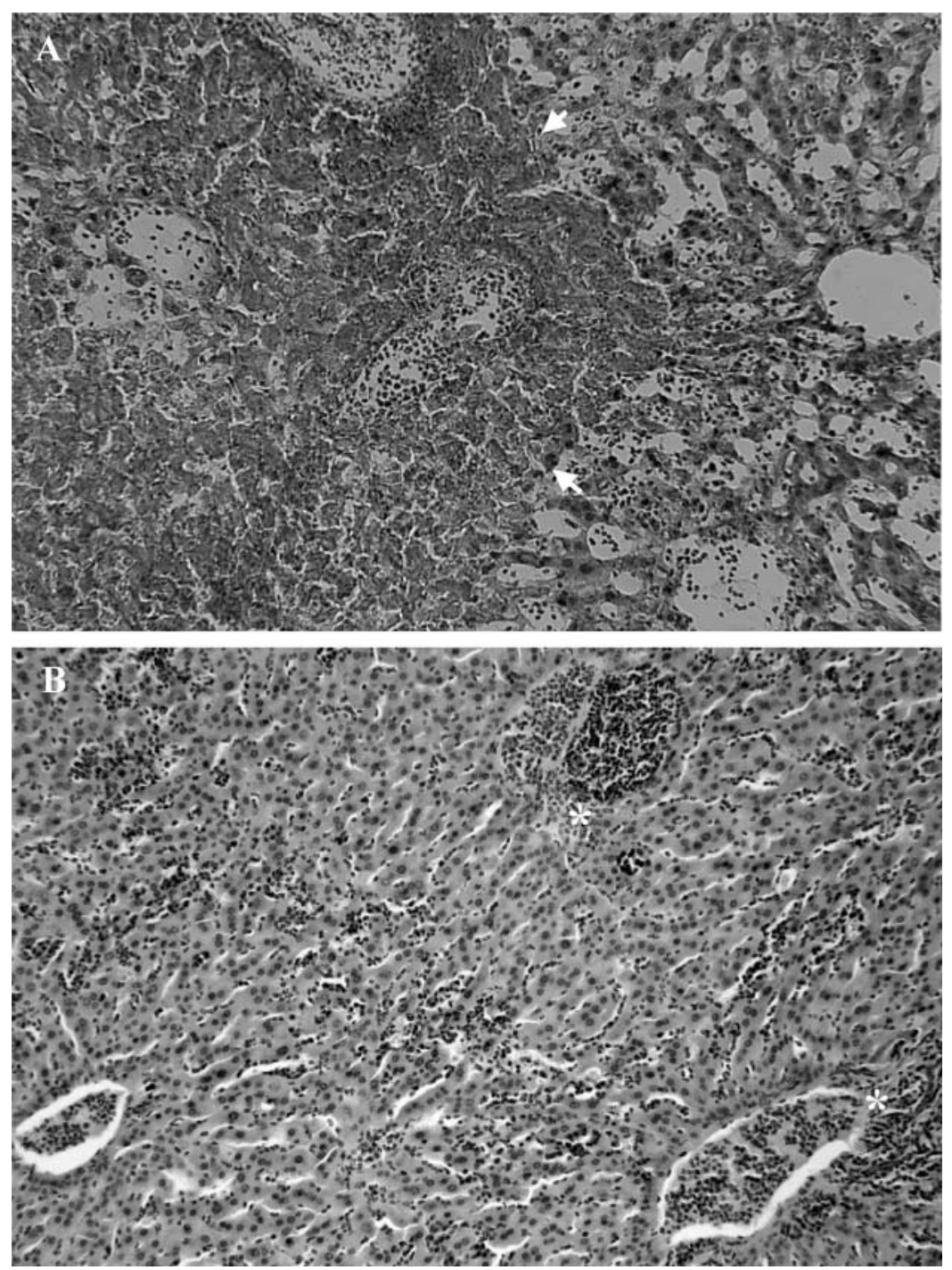

Figure 5 Improvement of liver necrosis in tumor-bearing mice following clodronate treatment. (A) H\&E stain revealed patchy necrosis (arrow) in the liver of untreated mice.

(B) Necrosis was greatly improved in clodronate-treated mice. Increased neutrophil sequestration and transmigration in the hepatic vasculature (asterisk) was seen in clodronate-treated mice (original magnification, $\times 200$ ).

Clodronate was reported to exert growth and cytokine inhibitory effects through impairment of intracellular ATP levels by its non-hydrolyzable metabolite, $\mathrm{AppCCl}_{2} \mathrm{p}$, following cellular metabolism (Monkkonen et al. 2001). Although cellular uptake of clodronate was low $(\sim 0 \cdot 04 \%)$, the capacity of epithelial cells to metabolize to $\mathrm{AppCCl}_{2} \mathrm{p}$ was comparable to that of macrophages (Monkkonen et al. 2003). In our study, clodronate suppressed cell growth and production of proinflammatory cytokines in Thena-Nu cells in a dose- and time-dependent manner. Dosedependent reduction of $\mathrm{NK}-\kappa \mathrm{B}$ activity in Thena-Nu cells following clodronate treatment was demonstrated by western blotting (data not shown), suggesting that suppression of NF- $\mathrm{KB}$ activity may also be involved in clodronate-induced growth and cytokine inhibitory effects (Makkonen et al. 1999).

The anti-tumor effect of clodronate was associated with dose and time of exposure (Shipman et al. 1997, Senaratne et al. 2000, Sonnemann et al. 2001). Previous studies, complimented by our results, suggest that the anti-tumor effect of clodronate is cell-type specific. Study on melanoma cells showed that treating with clodronate at $1000 \mu \mathrm{M}$ did not significantly change cell-cycle distribution, but tended to accumulate in $\mathrm{G}_{0} / \mathrm{G}_{1}$ phase (Forsea et al. 2004). Consistently, Thena-Nu cells treated with clodronate induced cytostasis in Thena-Nu cells. 
Table 1 Levels of human cytokines in sera and tumor extracts of Thena-Nu-bearing mice. Mice were treated with clodronate or left untreated and serum was collected at the time of death. Levels of human cytokines in mouse sera were assayed by the ELISA method. Results are expressed as picogram per milliliter. Note that all human cytokines were undetectable in sera of non-tumor-bearing mice

\begin{tabular}{|c|c|c|}
\hline & Serum $(\mathrm{pg} / \mathrm{ml})$ & Tumor (ng/g tissue \\
\hline \multicolumn{3}{|l|}{ IL-6 } \\
\hline Untreated & $1156 \cdot 4 \pm 128 \cdot 7$ & $134 \cdot 38 \pm 23 \cdot 76$ \\
\hline Clodronate & $622 \cdot 2 \pm 73 \cdot 8^{\dagger}$ & $72 \cdot 07 \pm 8 \cdot 22^{+}$ \\
\hline \multicolumn{3}{|l|}{$T N F-\alpha$} \\
\hline Untreated & $37 \cdot 7 \pm 4 \cdot 7$ & $1 \cdot 24 \pm 0 \cdot 25$ \\
\hline Clodronate & $20 \cdot 3 \pm 3 \cdot 2 *$ & $0.97 \pm 0.13$ \\
\hline \multicolumn{3}{|l|}{ LIF } \\
\hline Untreated & $1156 \cdot 7 \pm 114 \cdot 7$ & $2 \cdot 72 \pm 0 \cdot 76$ \\
\hline Clodronate & $1138 \cdot 8 \pm 264 \cdot 6$ & $2 \cdot 85 \pm 0 \cdot 42$ \\
\hline \multicolumn{3}{|l|}{$G-C S F$} \\
\hline Untreated & $2881 \cdot 3 \pm 547 \cdot 1$ & $221 \cdot 43 \pm 19 \cdot 68$ \\
\hline Clodronate & $1130 \cdot 2 \pm 379 \cdot 2 *$ & $198 \cdot 21 \pm 25 \cdot 83$ \\
\hline
\end{tabular}

${ }^{*} P<0 \cdot 05 ;{ }^{+} P<0 \cdot 01$. Serum $(\mathrm{pg} / \mathrm{ml})$ and tumor (ng/g tissue).

Our subsequent animal studies demonstrated that treatment with clodronate reduced tumor progression, attenuated cachexia, and prolonged survival in Thena-Nu-bearing mice. However, the cessation of drug treatment resulted in a gradual disease progression, suggesting that a longer period of treatment is required. The dosage we used in animal studies is clinically obtainable $(\sim 10 \mathrm{mg} / \mathrm{kg})$, as compared with that used in treating hypercalcemia in human subjects $(\sim 25 \mathrm{mg} / \mathrm{kg}$ for a $60 \mathrm{~kg}$ individual). Two tumor-bearing mice receiving clodronate treatment 5 weeks after inoculation did not show any improvement, suggesting that early treatment is required to obtain better outcome.

Significant reduction in serum levels of human cytokines, including IL-6, TNF- $\alpha$, and G-CSF, was detected in clodronate-treated mice; however, we did not detect a significant difference in serum LIF levels between these two groups. While redundancy of the cytokine network was observed, the cytokine profile following clodronate discontinuation may suggest the major role of LIF in this animal model of cancer cachexia. We did not detect levels of mouse cytokines due to insufficient serum. Nevertheless, all these four human cytokines have been reported to react with mouse cells by binding to their respective receptors (Demetri \& Griffin 1991, Tartaglia et al. 1991, Peters et al. 1996).

TNF- $\alpha$ was reported to play the major role of cachexia in numerous human diseases and animal models (Tisdale 2002). Prolonged exposure to TNF- $\alpha$ has been shown to stimulate protein loss in skeletal muscle cells directly by NF- $\kappa \mathrm{B}$ activation (Ladner et al. 2003). TNF- $\alpha$ may also act indirectly to increase expression of other cachectic factors (Billingsley et al. 1996) or work in corporation with other factors to induce muscle protein loss (Acharyya et al. 2004). Therefore, continuous production of TNF- $\alpha$, IL- 6 , and LIF in our model may activate NF- $\kappa \mathrm{B}$ to release many of the same cytokines in a positive feedback response and further aggravate the disease. Clodronate treatment significantly reduced serum levels of TNF- $\alpha$ and IL-6, but not LIF, and attenuated cachexia in Thena-Nu-bearing mice; tumor cytostasis and reduced s.c. fat wasting were also observed. The observation of reduced fat wasting in tumor-bearing mice is supposed to be ascribed to reduction in serum IL-6 levels following clodronate treatment, as IL-6 has been reported to deplete fat tissues in mice (Greenberg et al. 1992). Studies to elucidate the mechanisms of action of clodronate in this cachectic animal model are underway.

Histopathologically, Thena-Nu-injected mice demonstrated severe liver pathology, characterized by massive liver necrosis surrounded by degenerated hepatocytes with heavy neutrophil infiltration (Fig. 5A). Proinflammatory cytokinemediated neutrophil-induced organ damage has been well documented in several situations (Jaeschke \& Smith 1997); nevertheless, it was seldom reported in tumor-bearing hosts. The pathological changes in Thena-Nu-injected mice were similar to those observed in nude mice xenotransplanted with human lung cancer cell lines producing high levels of G-CSF (Suzuki et al. 1993). Mice injected with murine marrow cells containing G-CSF cDNA insert showed high serum G-CSF levels and heavy neutrophil infiltration in the liver; however, no liver damage was observed (Chang et al. 1989), suggesting that other factors participated in the process of liver necrosis seen in Thena-Nu-bearing mice. Reactive oxygen species and proteases, generated by infiltrating neutrophils after stimulation with TNF- $\alpha$, were demonstrated to induce hepatocyte necrosis directly (Jaeschke et al. 2002). Furthermore, IL-6 was shown to augment neutrophil cytotoxic potential by enhancing release of estalase and superoxide (Johnson et al. 1998). LIF was also reported to induce neutrophil leukocytosis (Metcalf \& Gearing 1989a) and liver necrosis in mice (Metcalf \& Gearing 1989b). In this context, the reduction of liver necrosis might be due to a reduction in serum cytokine levels following the clodronate treatment. Interestingly, profound neutrophil extravasation and transmigration in the hepatic vasculature were seen in clodronatetreated mice, suggesting that neutrophil-induced liver necrosis should be found if clodronate-treated mice were not killed. Liver necrosis may compromise anti-cancer therapy; accordingly, clodronate-induced improvement of liver pathology may enhance chemotherapeutic efficacy, which is worthy of further study.

In conclusion, we demonstrated that clodronate significantly reduced cell proliferation and cytokine production of Thena-Nu cells in vitro, and effectively alleviated cachexia and prolonged survival in tumor-bearing nude mice. Clinical trials utilizing clodronate on cancer cachexia are warranted.

\section{Acknowledgements}

This work is supported in part by grants from National Science Council, Taiwan (NSC91-2314-B-182A-025 and NSC92-2314-B-182A-049) and a grant from Chang Gung 
medical research fund (CMRP1164). The authors would like to thank Dr Ning Li, Department of Pathology, Chang Gung Memorial Hospital, Keelung, for performing histopathology, and Dr Chin-Hwa Sun, Institute of Applied Economics, National Taiwan Ocean University, for statistical analysis. The authors declare that there is no conflict of interest that would prejudice the impartiality of this scientific work.

\section{References}

Acharyya S, Ladner KJ, Nelson LL, Damrauer J, Reiser PJ, Swoap S \& Gutrridge DC 2004 Cancer cachexia is regulated by selective targeting of skeletal muscle gene products. Journal of Clinical Investigation 114 $370-378$.

Billingsley KG, Fraker DL, Strassmann G, Loeser C, Fliot HM \& Alexander HR 1996 Macrophage-derived tumor necrosis factor and tumor-derived leukemia inhibitory factor and interleukin-6: possible cellular mechanisms of cancer cachexia. Annals of Surgical Oncology 329 35 .

Chang JM, Metcalf D, Gonda TJ \& Johnson GR 1989 Long-term exposure to retrovirally expressed granulocyte-colony-stimulating factor induces a nonneoplastic granulocytic and progenitor cell hyperplasia without tissue damage in mice. Journal of Clinical Investigation 84 1488-1496.

Chang JWC, Yeh KY, Shen YC, Hsieh JJ, Chuang CK, Liao SK, Tsai LH \& Wang CH 2003 Production of multiple cytokines and induction of cachexia in athymic nude mice by a new anaplastic thyroid carcinoma cell line. Journal of Endocrinology 179 387-394.

Demetri GD \& Griffin JD 1991 Granulocyte colony-stimulating factor and its receptor. Blood 78 2791-2808.

Diel IJ, Solomayer E, Costa SD, Gollan C, Goerner R, Wallwiener D, Kaufmann M \& Bastert G 1998 Reduction in new metastases in breast cancer with adjuvant clodronate treatment. New England Journal of Medicine $339357-363$

Forsea AM, Muller C, Riebeling C, Orfanos CE \& Geilen CC 2004 Nitrogen-containing bisphosphonates inhibit cell cycle progression in human melanoma cells. British Journal of Cancer 91 803-810.

Frith JC, Monkkonen J, Blackburn GM, Russel RG \& Rogers MJ 1997 Clodronate and liposome-encapsulated clodronate are metabolized to a toxic ATP analog, adenosine $5^{\prime}-(\beta, \gamma$-dichloromethylene) triphosphate, by mammalian cells in vitro. Journal of Bone and Mineral Research 12 1358-1367.

Giuliani N, Pedrazzoni M, Passeri G \& Girasole G 1998 Bisphosphonates inhibit IL-6 production by human osteoblast-like cells. Scandinavian Journal of Rheumatology 27 38-41.

Greenberg AS, Nordan RP, McIntosh J, Calvo JC, Scow RO \& Jablons D 1992 Interleukin 6 reduces lipoprotein lipase activity in adipose tissue of mice in vivo and in 3T3-L1 adipocytes: a possible role for interleukin 6 in cancer cachexia. Cancer Research 52 4113-4116.

Jaeschke H \& Smith CW 1997 Mechanisms of neutrophil-induced parenchymal cell injury. Journal of Leukocyte Biology 61 647-653.

Jaeschke H, Gores GJ, Cederbaum AI, Hinson JA, Pessayre D \& Lemasters JJ 2002 Mechanisms of hepatotoxicity. Toxicological Sciences 65 166-176.

Johnson JL, Moore EE, Tamura DY, Zallen G, Biffl WL \& Silliman CC 1998 Interleukin-6 augments neutrophil cytotoxic potential via selective enhancement of elastase release. Journal of Surgical Research 76 91-94.

Kelland LR 2004 Of mice and men: values and liabilities of the athymic nude mouse model in anticancer drug development. European Journal of Cancer 40 $827-836$.

Kurebayashi J, Yamamoto S, Otsuki T \& Sonoo H 1999 Medroxyprogesterone acetate inhibits interleukin 6 secretion from KPL-4 human breast cancer cells both in vitro and in vivo: a possible mechanism of the anticachectic effect. British Journal of Cancer 79 631-636.
Ladner KJ, Caligiuri MA \& Guttridge DC 2003 Tumor necrosis factorregulated biphasic activation of $\mathrm{NF}-\kappa \mathrm{B}$ is required for cytokine-induced loss of skeletal muscle gene products. Journal of Biological Chemistry 278 2294-2303.

Langen RC, van der Velden JL, Schols AM, Kelders MC, Wouters EF \& Janssen-Heininger YM 2004 Tumor necrosis factor-alpha inhibits myogenic differentiation through MyoD protein destabilization. FASEB Journal 18 227-237.

Llovera M, Garcia-Martinez C, Agell N, Lopez-Soriano FJ \& Argiles JM 1995 Muscle wasting associated with cancer cachexia is linked to an important activation of the ATP-dependent ubiquitin-mediated proteolysis. International Journal of Cancer 61 138-141.

Llovera M, Garcia-Martinez C, Agell N, Lopez-Soriano FJ \& Argiles JM 1997 TNF can directly induce the expression of ubiquitin-dependent proteolytic system in rat soleus muscles. Biochemical and Biophysical Research Communications 230 238-241.

Loprinzi CL, Schaid DJ, Dose AM, Burnham NL \& Jensen MD 1993 Body composition changes in patients who gain weight while receiving megestrol acetate. Journal of Clinical Oncology 11 152-154.

Makkonen N, Salminen A, Rogers MJ, Frith JC, Urtti A, Azhayeva E \& Monkkonen J 1999 Contrasting effects of alendronate and clodronate on RAW 264 macrophages: the role of a bisphosphonates metabolite. European Journal of Pharmaceutical Sciences 8 109-118.

Mantovani G, Maccio A, Lai P, Massa E, Ghiani M \& Santona MC 1998 Cytokine activity in cancer-related anorexia/cachexia: role of megestrol acetate and medroxyprogesterone acetate. Seminars in Oncology 25 45-52.

Metcalf D \& Gearing DP 1989a A myelosclerotic syndrome in mice engrafted with cells producing high levels of leukemia inhibitory factor (LIF). Leukemia 3 847-852.

Metcalf D \& Gearing DP $1989 b$ Fatal syndrome in mice engrafted with cells producing high levels of leukemia inhibitory factor (LIF). PNAS $\mathbf{8 6}$ 5948-5952.

Monkkonen J, Pennanen N, Lapinjoki S \& Urtti A 1994 Clodronate (dichloro-methylene bisphosphonate) inhibits LPS-stimulated IL-6 and TNF production by RAW264 cells. Life Sciences 54 PL229-PL235.

Monkkonen H, Rogers MJ, Makkonen N, Niva S, Auriola S \& Monkkonen J 2001 The cellular uptake and metabolism of clodronate in RAW 264 macrophages. Pharmaceutical Research 18 1550-1555.

Monkkonen H, Tormalehto S, Asunmaa K, Niemi R, Auriola S, Vepsalainen J \& Monkkonen J 2003 Cellular uptake and metabolism of clodronate and its derivatives in Caco-2 cells: a possible correlation with bisphosphonateinduced gastrointestinal side-effects. European Journal of Pharmacentical Sciences 19 23-29.

Noguchi Y, Yoshikawa T, Matsumoto A, Svaninger G \& Gelin J 1996 Are cytokines possible mediators of cancer cachexia? Surgery Today Japanese Journal of Surgery 26 467-475.

Peters M, Jacobs S, Ehlers M, Vollmer P, Mullberg J, Wolf E, Brem G, Meyer zum Buschenfelde KH \& Rose-John S 1996 The function of the soluble interleukin 6 (IL-6) receptor in vivo: sensitization of human soluble IL-6 receptor transgenic mice towards IL-6 and prolongation of the plasma half-life of IL-6. Journal of Experimental Medicine 183 1399-1406.

Rogers MJ, Brown RJ, Hodkin V, Blackburn GM, Russell RGR \& Watts DJ 1996 Bisphosphonates are incorporated into adenine nucleotides by human aminoacyl-tRNA synthetase enzymes. Biochemical and Biophysical Research Communications 224 863-869.

Sauty A, Pecherstofer M, Simmer-Roth I, Fioroni P, Juillerat L, Markert M, Ludwig H, Leuenberger P, Burckhardt P \& Thiebaud D 1996 Interleukin-6 and tumor necrosis factor $\alpha$ levels after bisphosphonate treatment in vitro and in patients with malignancy. Bone 18 133-139.

Senaratne SG, Pirianov G, Mansi JL, Arnett TR \& Colston KW 2000 Bisphosphonates induce apoptosis in human breast cancer cell lines. British Journal of Cancer 82 1459-1468.

Shipman CM, Rogers MJ, Apperley JF, Graham R, Russell G \& Croucher PI 1997 Bisphosphonates induce apoptosis in human myeloma cell lines: a novel anti-tumor activity. British Journal of Haematology 98 665-672.

Sonnemann J, Eckervogt V, Truckenbrod B, Boos J, Winkelmann W \& van Valen F 2001 The bisphosphonate pamidronate is a potent inhibitor of human osteosarcoma cell growth in vitro. Anti-Cancer Drugs 12 459-465. 
Suzuki A, Takahashi T, Okuno Y, Seko S, Fukuda Y, Nakamura K, Fukumoto M, Konaka Y \& Imura H 1993 Liver damage in patients with colony-stimulating factor-producing tumors. American Journal of Medicine $94125-132$.

Tamura S, Fujimoto-Ouchi K, Mori K, Endo M, Matsumoto T, Eda H, Tanaka Y, Ishitsuka H, Tokita H \& Yamaguchi K 1995 Involvement of human interleukin 6 in experimental cachexia induced by a human uterine cervical carcinoma xenograft. Clinical Cancer Research 1 1353-1358.

Tartaglia LA, Weber RF, Figari IS, Reynolds C, Palladino MA, Jr. \& Goeddel DV 1991 The two different receptors for tumor necrosis factor mediate distinct cellular responses. PNAS 88 9292-9296.

Tisdale MJ 2002 Cachexia in cancer patients. Nature Review of Cancer 2 862-871.

Tsujinaka T, Fujita J, Ebisui C, Yano M, Kominami E, Suzuki K, Tanaka K, Katsume A, Ohsugi Y, Shiozaki H et al. 1996 Interleukin 6 receptor antibody inhibits muscle atrophy and modulates proteolytic systems in interleukin 6 transgenic mice. Journal of Clinical Investigation 97 244-249.

Yamamoto Y \& Gaynor RB 2001 Therapeutic potential of inhibition of the NF-KB pathway in the treatment of inflammation and cancer. Journal of Clinical Investigation 107 135-142.

Received in final form 29 April 2006

Accepted 4 May 2006

Made available online as an Accepted Preprint 29

May 2006 